\title{
Corporate governance, pyramid ownership, and firm value: Evidence from Vietnam
}

\author{
TRAN THI HAI LYa, NGUYEN KIM DUC ${ }^{b}$ \\ ${ }^{a, b}$ University of Economics HCMC
}

\begin{abstract}
ART I C L E I NFO A B T RACT
Received 15 Mar. 2016

Revised 30 Aug. 2016

Accepted 1 Jan. 2018

Available online

12 January 2018

JEL classifications:

C24; D22; G32

\section{KEYWORDS}

Corporate governance

This paper examines the relation among corporate governance practices, pyramid ownership structure, and firm value by using a sample of Vietnamese listed firms. Using a sample of 103 non-financial firms listed on HOSE for the period from 2012 to 2014, and employing two-stage least square regression (2SLS) to deal with potential endogeneity, we find that some indicators, commonly adopted as a key components of corporate governance, such as size or independence of board of directors, are imperfect proxies for corporate governance practices. Our results indicate that it is better to employ a corporate governance index (CGI), including 117 criteria developed by Connelly, Limpaphayom, and Nagarajan (2012) since it allows for more comprehensive estimation of corporate governance. More interestingly, our results show that the pyramid ownership plays an important role in the effect of corporate governance on firm value. The results are consistent regardless of whether companies have high or low family ownership.
\end{abstract}

index

Corporate governance

Pyramid ownership

\footnotetext{
a Email: hailyth@ueh.edu.vn*,correspondence author

bEmail: ducnk.tdg@ueh.edu.vn
} 


\section{Introduction}

Maximizing firm value is the most vital goal of any enterprises. In the modern corporations, shareholders and their representatives (board of directors) do not manage company directly. Instead, management teams are authorized to make decisions on behalf of shareholders. The separation between the ownership and management rights causes the agency problem (Jensen \& Meckling, 1976). Therefore, shareholders need a procedure, which is known as corporate governance, to control the management board and to ensure their decisions are to maximize the shareholders' value.

There are several empirical studies investigating the relation between corporate governance and firm value in other countries as well as in Vietnam. Based on these studies, the proxies for corporate governance can be divided into two groups: (i) conventional individual governance indicators, such as the board independence (Hermalin \& Weisbach, 1991), CEO duality (Chen, Lin, \& Yi, 2008), board size (Yermack, 1996); and (ii) a set of separate criteria to evaluate the overall quality of corporate governance practices, called the corporate governance index (CGI). Conventional individual indicators are not good proxies for corporate governance practices, while previous CGIs for US companies (Gompers, Ishii, \& Metrick, 2003; Brown \& Caylor, 2006; Bebchuk, Cohen, \& Ferrell, 2009) and German firms (Drobetz, Schillhofer, \& Zimmerman, 2003) are difficult to apply to ASEAN markets (Connelly, Limpaphayom, \& Nagarajan, 2012) because these indexes are developed to assess the extent of takeover defences.

A corporate governance index that is gauged from 117 separate criteria developed by Connelly, Limpaphayom, and Nagarajan (2012) is known as the most comprehensive index of the quality of corporate governance practices (we call it a new corporate governance index or CGI in short form). This paper will examine the validity of this corporate governance index using a sample of Vietnamese listed firms. We ask whether CGI a good proxy of corporate governance practices in Vietnam in determining firm value. To do so, we compare this CGI with conventional indicators of corporate governance. In fact, benefits resulting from a good corporate governance practices might be cancelled out by the presence of pyramid structures (Connelly, Limpaphayom, \& Nagarajan, 2012). To take this point into account, we further investigate whether the relation between corporate governance and firm value is moderated by pyramid structures.

Our study contributes to the literature on corporate governance and firm performance. It provides an understanding about the role of corporate governance in explaining firm value under the moderation of pyramid ownership and family ownership that is common in Vietnam.

The rest of the paper is structured as follows. Section 2 presents the literature review. Section 3 describes the model, estimation method and data. Section 4 presents and discusses 
the results. Section 5 concludes the paper.

\section{Literature review}

\subsection{Theoritical framework}

The new CGI is an index that measures corporate governance. Based on Organization for Economic Cooperation and Development (OECD, 1999, 2004), Connelly, Limpaphayom and Nagarajan (2012) developed this index which included 117 criterias and applied it for Thailand market. CGI is a set of indicators including a number of mandatory and voluntary information that reflect the quality of corporate governance practices. Therefore, CGI might be accepted as the fully corporate governance index.

The first version of CGI included 57 criterias. After being applied in 2000, 2002, and 2004, some questions in the first version were modified, while some others questions were added, resulting in a current (new) version of CGI with 117 separate criteria. Although the number and format of questions have been changed, the structure of CGI still remains in line with OECD's corporate governance principles (OECD, 1999). These criterias are classified into five groups: (i) Shareholders' rights (total of 22 criterias with maximum score of 42); (ii) Equitable treatment of shareholders (total of 13 criterias, maximum score of 24); (iii) Role of stakeholders (total of 9 criterias with maximum score of 14); (iv) Disclosure and transparency (total of 32 criterias with maximum score of 40); (v) Board responsibilities (total of 41 criterias with maximum score of 50) (see Connelly, Limpaphayom, \& Nagarajan (2012) for more details).

Ownership and controlling rights can be shown by cash flow rights and voting rights respectively. In most cases, it follows the one share, one vote rule. However, this may not be a case when there are indirect shareholdings stemming from the differences in measuring the cash flow and voting rights. Pyramid ownership exists if a firm has indirect ownership structure. In other words, pyramid structure is a top-down chain of control by affiliated firms (La Porta, Lopez-de-Silanes, \& Shleifer, 1999), in which, final shareholders are located at the top of the pyramid, while intermediary firms are located underneath. This structure leads to the separation between ownership and voting rights in companies located in the lower part of the pyramid (Claessens, Djankov, \& Lang, 2000). Therefore, pyramid structure allows shareholders to hold fewer shares but possess greater voting rights (Connelly, Limpaphayom, \& Nagarajan, 2012).

In the literature, information asymmetry is a key hypothesis explaining the relationship between shareholders and managers. According to the agency theory introduced by Jensen \& Meckling (1976), agency problem will appear when one or more persons (principals) employs other person (agents) to perform certain tasks on principals' behalf. The principals delegate decision-making rights to agents with a desire that the agent will act to maximize their interests. However, due to information asymmetry the agent might has different 
interests (Eisenhardt, 1989). This means that managers can make decisions that maximize their personal benefits or they try to avoid bearing risk, instead of maximizing firm's value. Therefore, shareholders have to control the activities of management teams to ensure that the teams serves their interests. There are some ways for shareholders to limit the agency problem such as establishing incentive schemes and appropriate compensations. Among them, corporate governance with the supervision of the board of directors is a popular practice that is expected to mitigate the divergences of management from shareholders' interest. Besides, there are agency conflicts between majority shareholders and outside/minority shareholders in family firms that are common in developing countries, stemming from the lack of legal rights and investor protection. Therefore, corporate governance is expected to handle these conflicts in these companies.

\subsection{Corporate governance and firm value}

Previous empirical studies usually employ conventional proxies for corporate governance such as board composition (Agrawal \& Knoeber, 1996; Hermalin \& Weisbach, 2003), the ratio of independent directors (Hermalin \& Weisbach, 1991; Daraghma \& Alsinawi, 2010; Rouf, 2011; Turki \& Sedrine, 2012), CEO duality (Chen, Lin, \& Yi, 2008; Rouf, 2011), board size (Yermack, 1996; Eisenberg, Sundgren, \& Wells, 1998; Andres, Azofra, \& Lopez, 2005; Rouf, 2011), ownership concentration (Himmelberg et al., 1999; Morck et al., 1988; Barontini \& Caprio 2006). The fact is that, findings from these studies are inconsistent. One could not conclude the benefits coming from good corporate governance practices (Cheung et al., 2014). Because of inconclusive results, a composite corporate governance index seems attractive. A composite index of corporate governance will mitigate the conflict across individual corporate indicators.

There are several studies examining the impact of corporate governance on firm value. In developed countries, Gompers, Ishii, and Metrick (2003), Drobetz, Schillhofer, and Zimmerman (2003), Bebchuk, Cohen and Ferrell (2009) and Brown and Caylor (2006) are four outstanding studies in this field. These studies attempt to construct composite corporate governance indexes and then empirically test the relation between constructed CGIs and firm value. However, their indexes are difficult to apply to ASEAN markets because they are primarily focus on takeover defenses that is very rare in ASEAN countries. Therefore, researchers still construct CGIs for emerging countries in Asia, such as Korea (Black et al., 2006), HongKong (Cheung et al., 2007), Thailand (Connelly, Limpaphayom, \& Nagarajan, 2012). Interestingly, when using the same CGI as a proxy for corporate governance, all of the studies report a significantly and consistently positive correlation between corporate governance and firm value. This implies that to evaluate the impact of corporate governance on firm performance, one needs an appropriate measure for corporate governance.

Although corporate governance is found as a determinant of firm value, one may ask if the relationship between corporate governance remains unchanged when existing a 
complex ownership structure, such as pyramid ownership. In the pyramid ownership structure, final shareholders can benefit for themselves but cost non-controlling shareholders. This exploitation might be even stronger in countries where legal regulations to protect non-controlling shareholders are weak (Xia, 2008). Claessens et al. (2002) support this argument. They document the evidence in eight countries in East Asia that firm value increases with an increase in ownership of final control shareholders, but decreases with an increase in their voting rights. Subsequent studies in India (Bertrand, Mehta, \& Mullainathan, 2002), emerging markets (Lins, 2003), and countries in East Asia (Lemmon \& Lins, 2003) also report similar results. Connelly, Limpaphayom, and Nagarajan (2012) investigates the impact of pyramid ownership on the relation between corporate governance and firm value and find that there is a positive relation between CGI and firm value for their full sample. However, this relation is significance only for firms those do not have pyramid structure. These findings indicate that there is an important role of pyramid structures moderating in the relation between corporate governance and firm value.

\section{Data and Methodology}

\subsection{Empirical model}

CGI developed by Connelly, Limpaphayom, and Nagarajan (2012) have three advantages making it more effective than conventional measures and previous indexes. Firstly, CGI is a set of separate criteria so it might captures many dimensions of the quality of corporate governance. Secondly, CGI reveals the actually implemented practices since it reflects the corporate governance related activities and firm disclosures. In particular, CGI can reflect the missing indicators, match requirements by law, or achieve the international best practices. Finally, the index is developed based on the previous reliable foundations, including OECD's corporate governance principles, economic and financial theories, and empirical research findings. Because of these advantages of CGI, it will be employed as a composite corporate governance index in this study.

Following Connelly, Limpaphayom, and Nagarajan (2012) and Cheung et al. (2014), we first use conventional proxies for corporate governance such as board size and board independence (Model 1). Then, CGI will be included to evaluate the relation between corporate governance and firm value (Model 2).

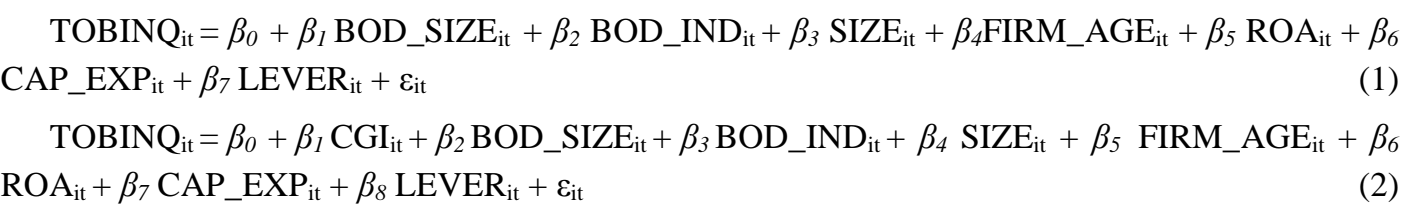

where TOBINQ ${ }_{i t}$ is a measure of firm value of firm $i$ at year $t$, all independent variables are presented in the Table 1. $\varepsilon_{i t}$ is the random error term.

Pooled OLS, Fixed Effects Model (FE) and Random Effects Model (RE) will be applied for the 
Model (1) to (4). F-test, LM-test (Breusch-Pagan Lagrange Multiplier), and Hausman-test will be used to select the most appropriate regression model.

\section{Table 1}

\section{Variable description}

\begin{tabular}{|c|c|c|}
\hline Variable & Name & Definition \\
\hline TOBINQ & Firm value & $\begin{array}{l}\text { Tobin's } Q \text { is the ratio of the book value of long- } \\
\text { term debt plus the market value of equity } \\
\text { divided by the book value of total assets }\end{array}$ \\
\hline TOBINQ_A & The past performance & The average Tobin's $Q$ of the last two years \\
\hline CGI & The corporate governance index & $\begin{array}{l}\text { A set of separate criteria to evaluate the overall } \\
\text { quality of corporate governance practices } \\
\text { including shareholders' rights, shareholders' } \\
\text { treatment, stakeholders' role, Disclosure and } \\
\text { transparency, and Board responsibilities }\end{array}$ \\
\hline CGI_A & Shareholders' rights & Total of 22 criterias with maximum score of 42 \\
\hline CGI_B & Shareholders' treatment & Total of 13 criterias, maximum score of 24 \\
\hline CGI_C & Stakeholders' role & Total of 9 criterias with maximum score of 14 \\
\hline CGI_D & Disclosure and transparency & Total of 32 criterias with maximum score of 40 \\
\hline CGI_E & Board responsibilities & Total of 41 criterias with maximum score of 50 \\
\hline BOD_SIZE & The size of board of directors & $\begin{array}{l}\text { The number of directors on the board of } \\
\text { directors }\end{array}$ \\
\hline BOD_IND & $\begin{array}{l}\text { The dependence of board of } \\
\text { directors }\end{array}$ & $\begin{array}{l}\text { The ratio of the number of independent } \\
\text { directors to board size }\end{array}$ \\
\hline SIZE & Firm size & The natural logarithm of total assets \\
\hline FIRM_AGE & The operating age of firm & $\begin{array}{l}\text { The natural logarithm of years since the firm } \\
\text { was founded }\end{array}$ \\
\hline $\mathrm{ROA}$ & Return on Assets & The ratio of earning after taxes to total assets \\
\hline CAP_EXP & Capital expenditures & The ratio of capital expenditures to total assets \\
\hline LEVER & Financial leverage & $\begin{array}{l}\text { The ratio of long-term debt divided by total } \\
\text { assets }\end{array}$ \\
\hline
\end{tabular}

There might be a potential endogeneity in the models of corporate governance and firm value arising from the concurrent relationship between them (Connelly, Limpaphayom, \& Nagarajan, 2012). Lehn, Patro, and Zhao (2007) show that controlling for past performance will eliminate this concurrent relation. Following Lehn, Patro, and Zhao (2007) and Connelly, Limpaphayom, and Nagarajan (2012), we include a past performance as a control variable in the Model (1) and Model 
(2), leading to Eq. (3) and (4). The past performance is defined as average Tobin's Q of the last two years. Then, these models will be estimated by two-stage least squares (2SLS) regression to obtain unbiased and consistent estimates.

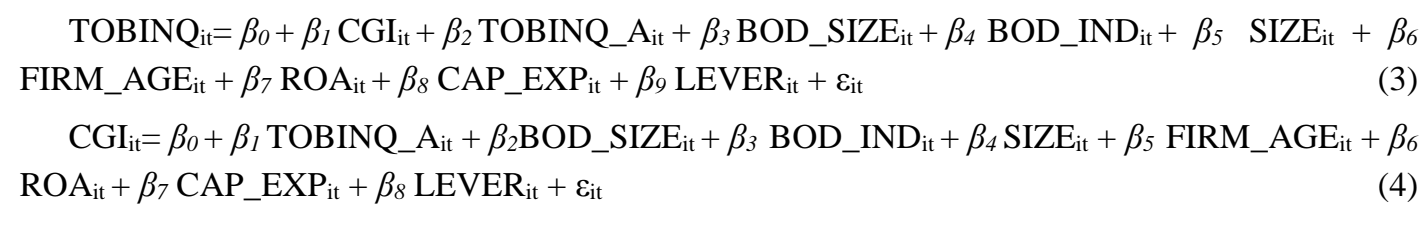

\subsection{Data}

The sample in this study includes 103 non-financial firms listed on Ho Chi Minh Stock Exchange (HoSE) during the period from 2012 to 2014. We collect data from financial statements, annual reports, enterprises' regulations, corporate governance regulations, the notice of invitation to the general meeting of shareholders, attached documents in the notice of invitation, minutes and resolution of the general meeting, reports of board of directors, auditing reports, reports of the management board, board of directors resolution, and firms' websites.

We follow some criterias to construct our sample. Some items of CGI is not only marked at time $\mathrm{t}$ but also at time $\mathrm{t}-1, \mathrm{t}-2$. The number of maximum years in the past is two (year $\mathrm{t}-2$, and year $\mathrm{t}-1$ ). Thus, to mark CGI during the period from 2012 to 2014, the data is collected from 2010 to 2014. Therefore, delisted firms, non-operating firms, restructured firms during this period will be excluded from the sample.

As stated before, pyramid ownership may drive the corporate governance-firm value relationship, we thus divide the full sample into two sub-samples, one with the existence of pyramid structure and another without the existence of pyramid structure. A firm is classified as existing pyramid ownership if cash flow rights are not equal to voting rights. In other words, a company with a pyramid structure will have at least a shareholder who is a subsidiary of another company.

We further classify firms with pyramid ownership into two groups, one has low family ownership and other has high family ownership. From information on anual reports and other public disclosures, we list the top ten shareholders of each company. Next, we identify total family ownership by counting the number of shares held by shareholders with the same last name as the family or shareholders who have familial relationships (relatives) even if the last names are different. Family relationships are identified from corporate governance reports. Companies are classified as "high family ownership" if the total of family ownership exceeds the median ownership for all family firms in the sample (Connelly, Limpaphayom, \& Nagarajan, 2012).

Table 2 presents the descriptive statistics for variables. Figure 1 shows the changes of CGI and sub-components of CGI in the period from 2012 to 2014. 
Table 2

Descriptive statistics

\begin{tabular}{|c|c|c|c|c|}
\hline & \multirow[b]{2}{*}{ All firms } & \multicolumn{3}{|c|}{ Pyramid structure } \\
\hline & & $\begin{array}{c}\text { Non-Existence } \\
\text { (1) }\end{array}$ & $\begin{array}{c}\text { Existence } \\
\text { (2) }\end{array}$ & $\begin{array}{c}t-\text { Statistic } \\
(1-2)\end{array}$ \\
\hline \multirow{2}{*}{ TOBINQ } & 0.689 & 0.664 & 0.771 & $-1.785^{*}$ \\
\hline & $(0.446)$ & $(0.392)$ & $(0.586)$ & $(0.598)$ \\
\hline \multirow[t]{2}{*}{ BOD_SIZE } & 5.880 & 5.873 & 5.903 & -0.158 \\
\hline & $(1.378)$ & $(1.441)$ & (1.153) & $(0.186)$ \\
\hline \multirow[t]{2}{*}{ BOD_IND } & 0.527 & 0.538 & 0.491 & 1.391 \\
\hline & $(0.253)$ & $(0.246)$ & $(0.274)$ & $(0.034)$ \\
\hline \multirow[t]{2}{*}{ SIZE } & 27.741 & 27.648 & 28.048 & $-2.581^{* *}$ \\
\hline & $(1.162)$ & $(1.154)$ & (1.143) & $(0.155)$ \\
\hline \multirow[t]{2}{*}{ FIRM_AGE } & 3.075 & 3.118 & 2.933 & $2.596^{* * *}$ \\
\hline & $(0.536)$ & $(0.529)$ & $(0.540)$ & $(0.072)$ \\
\hline \multirow[t]{2}{*}{ ROA } & 0.068 & 0.069 & 0.064 & 0.473 \\
\hline & $(0.079)$ & $(0.083)$ & $(0.062)$ & $(0.011)$ \\
\hline \multirow[t]{2}{*}{ CAP_EXP } & 0.054 & 0.052 & 0.059 & -0.844 \\
\hline & $(0.063)$ & $(0.062)$ & $(0.068)$ & $(0.009)$ \\
\hline \multirow[t]{2}{*}{ LEVER } & 0.103 & 0.103 & 0.104 & -0.068 \\
\hline & $(0.135)$ & $(0.137)$ & $(0.129)$ & $(0.182)$ \\
\hline \multirow[t]{2}{*}{ CGI } & 45.375 & 45.771 & 44.074 & $2.504^{* *}$ \\
\hline & (5.078) & (5.167) & $(4.567)$ & $(0.678)$ \\
\hline \multirow[t]{2}{*}{ CGI_A } & 33.981 & 34.890 & 30.986 & $2.482^{* *}$ \\
\hline & $(11.785)$ & $(12.126)$ & $(10.097)$ & $(1.573)$ \\
\hline \multirow[t]{2}{*}{ CGI_B } & 59.870 & 61.656 & 53.992 & $7.224^{* * *}$ \\
\hline & (8.514) & (7.787) & $(8.200)$ & (1.061) \\
\hline \multirow[t]{2}{*}{ CGI_C } & 41.320 & 39.633 & 46.875 & $-3.461^{* * *}$ \\
\hline & (15.823) & (15.212) & (16.615) & (2.092) \\
\hline \multirow[t]{2}{*}{ CGI_D } & 64.029 & 64.516 & 62.425 & $1.970^{* *}$ \\
\hline & (7.928) & (7.802) & (8.181) & (1.062) \\
\hline \multirow[t]{2}{*}{ CGI_E } & 34.202 & 34.007 & 34.844 & -0.917 \\
\hline & (6.786) & (6.833) & $(6.630)$ & (0.913) \\
\hline
\end{tabular}

Notes: Standard errors are shown in parentheses (.); $t$-Statistics are estimated for differences between for existence and non-existence pyramid structure; ${ }^{* * *} \mathrm{p}<0.01$, ${ }^{* *} \mathrm{p}<0.05$, and ${ }^{*} \mathrm{p}<0.1$ 


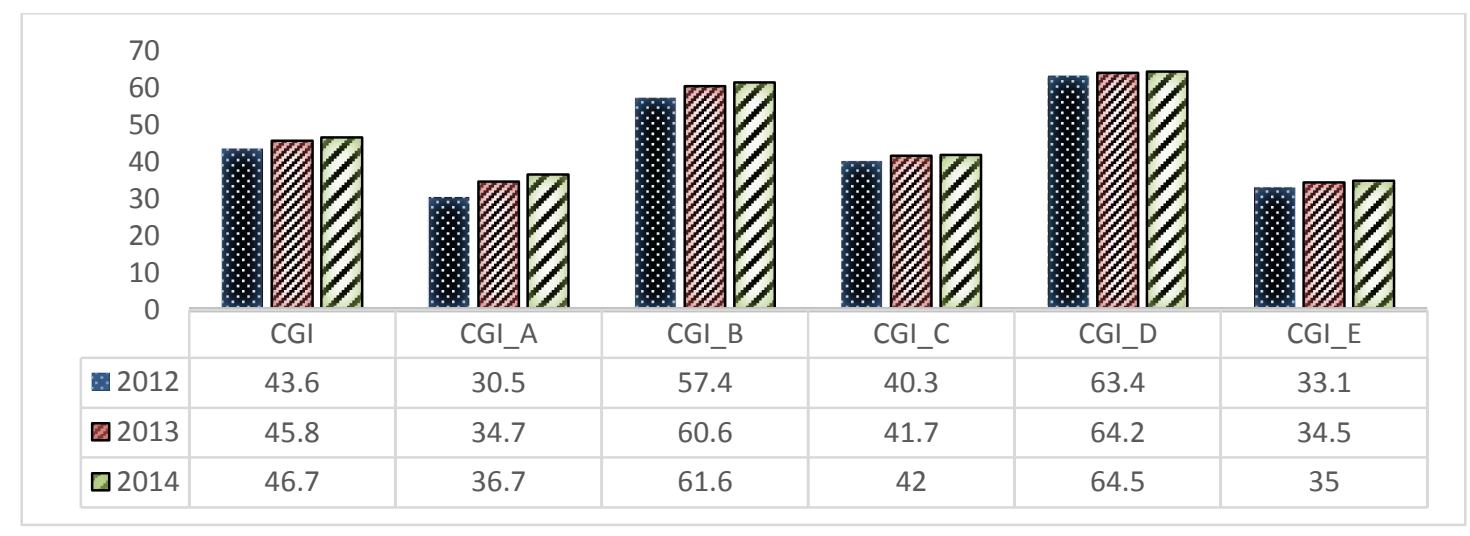

Figure 1. Average CGI scores during 2012-2014

The Pearson correlation results are reported in Table 3. Panel A and B present correlation coefficient between Tobin's Q and independent variables, between CGI index and five component groups of CGI respectively. Our (untabulated) results show that no correlation coefficients between explanatory variables is relatively highexceed, so multi-collinearity is not problematic in our study.

\section{Table 3}

Correlation matrix

\begin{tabular}{|c|c|c|c|c|c|c|c|c|c|c|c|}
\hline \multicolumn{12}{|c|}{ Panel A: Correlations among CGI and firm characteristics } \\
\hline & & & $(01)$ & $(02)$ & $(03)$ & $(04)$ & $(05)$ & $(06)$ & $(07)$ & $(08)$ & $(09)$ \\
\hline$(01)$ & \multicolumn{2}{|c|}{ TOBINQ } & 1.00 & & & & & & & & \\
\hline$(02)$ & \multicolumn{2}{|c|}{ BOD_SIZE } & 0.08 & 1.00 & & & & & & & \\
\hline$(03)$ & \multicolumn{2}{|c|}{ BOD_IND } & 0.15 & 0.21 & 1.00 & & & & & & \\
\hline$(04)$ & \multicolumn{2}{|l|}{ SIZE } & -0.15 & 0.28 & 0.10 & 1.00 & & & & & \\
\hline$(05)$ & \multicolumn{2}{|c|}{ FIRM_AGE } & 0.11 & 0.01 & -0.05 & -0.10 & 1.00 & & & & \\
\hline$(06)$ & \multicolumn{2}{|l|}{ ROA } & 0.56 & 0.00 & 0.18 & -0.09 & 0.01 & 1.00 & & & \\
\hline (07) & \multicolumn{2}{|c|}{ CAP_EXP } & 0.18 & 0.1 & -0.02 & 0.08 & -0.08 & 0.22 & 1.00 & & \\
\hline (08) & \multicolumn{2}{|l|}{ LEVER } & 0.00 & 0.10 & 0.00 & 0.29 & -0.02 & -0.22 & 0.16 & 1.00 & \\
\hline (09) & \multicolumn{2}{|l|}{ CGI } & 0.21 & 0.22 & -0.02 & 0.16 & 0.08 & 0.28 & -0.00 & -0.04 & 1.00 \\
\hline \multicolumn{12}{|c|}{ Panel B: Correlations among CGI and 5 sub-components of CGI } \\
\hline & & & & & & $(01)$ & $(02)$ & (03) & $(04)$ & (05) & (06) \\
\hline$(01)$ & CGI & & rate go & rnanc & & 1.00 & & & & & \\
\hline$(02)$ & CGI_A & & olders & ights & & 0.68 & 1.00 & & & & \\
\hline (03) & CGI_B & & olders & reatm & & 0.34 & 0.07 & 1.00 & & & \\
\hline (04) & CGI_C & & olders' & & & 0.42 & 0.07 & 0.04 & 1.00 & & \\
\hline (05) & CGI_D & & sure an & transp & rency & 0.50 & 0.10 & -0.01 & 0.04 & 1.00 & \\
\hline (06) & CGI_E & & respon & bilitie & & 0.61 & 0.08 & 0.15 & 0.26 & 0.17 & 1.00 \\
\hline
\end{tabular}

Notes: The bold correlations are statistically significant at $10 \%$ level. 


\section{Results}

Table 4 presents regression results with Pooled OLS, FE model, and RE model for the full sample. The three first columns show the relationship between conventional corporate governance indicators and firm value. While the three last columns show how firm value is related not only conventional corporate variables but also the composite index of corporate governance. Estimating regressions with conventional corporate governance indicators and the composite index as independent variables at the same time allow us to evaluate corporate governance practices generally.

Based on the results of F-test, LM-test and Hausman test, FE model is selected in all models in this study, we therefore discuss the results from FE estimations. The result of model (1) indicates that there is a significant positive relation between board dependence and firm value at $10 \%$ significance level. However, the coefficient for board size is not statistically significant. These results are consistent to those of Connelly, Limpaphayom and Nagarajan (2012). The authors argue that these variables only represent the "form" instead of the "substance" of the effective corporate governance practices. When we include the CGI variable in the model, the result shows that firm value is not significantly related to CGI.

\section{Table 4}

Regression results for the full sample

\begin{tabular}{lcccccc}
\hline \multirow{2}{*}{$\begin{array}{l}\text { Independent } \\
\text { Variables }\end{array}$} & Model (1) & & & Model $(2)$ & \\
\cline { 2 - 7 } & OLS & FE model & RE model & $\begin{array}{c}\text { Pooled } \\
\text { OLS }\end{array}$ & FE model & RE model \\
\hline CGI & & & & 0.0057 & 0.0027 & $0.0135^{* * *}$ \\
& & & & $(0.0044)$ & $(0.0051)$ & $(0.0040)$ \\
BOD_SIZE & $0.0291^{*}$ & 0.0806 & 0.0200 & 0.0246 & 0.0052 & 0.0071 \\
& $(0.0158)$ & $(0.021)$ & $(0.0176)$ & $(0.0162)$ & $(0.0218)$ & $(0.0177)$ \\
& {$[1.84]$} & {$[0.38]$} & {$[1.14]$} & {$[1.52]$} & {$[0.24]$} & {$[0.4]$} \\
BOD_IND & 0.0824 & $0.1860^{*}$ & $0.1667^{*}$ & 0.0985 & $0.1846^{*}$ & $0.1793^{* *}$ \\
& $(0.0842)$ & $(0.1116)$ & $(0.0929)$ & $(0.084)$ & $(0.1119)$ & $(0.0914)$ \\
& {$[0.98]$} & {$[1.67]$} & {$[1.79]$} & {$[1.16]$} & {$[1.65]$} & {$[1.96]$} \\
SIZE & & & & {$[1.29]$} & {$[0.52]$} & {$[3.34]$} \\
& $-0.0643^{* * *}$ & 0.0236 & -0.0219 & $-0.0684^{* * *}$ & 0.0192 & -0.0407 \\
& $(0.0191)$ & $(0.0781)$ & $(0.0292)$ & $(0.0194)$ & $(0.0788)$ & $(0.0293)$ \\
& {$[-3.37]$} & {$[0.3]$} & {$[-0.75]$} & {$[-3.54]$} & {$[0.24]$} & {$[-1.39]$} \\
FIRM_AGE & $0.0813^{* *}$ & $1.0203^{* * *}$ & $0.1881^{* * *}$ & $0.0773^{*}$ & $0.9674^{* * *}$ & $0.1511^{* *}$ \\
& $(0.0383)$ & $(0.2088)$ & $(0.0620)$ & $(0.0384)$ & $(0.2325)$ & $(0.0622)$ \\
& {$[2.12]$} & {$[4.89]$} & {$[3.03]$} & {$[2.02]$} & {$[4.16]$} & {$[2.43]$} \\
ROA & $3.2288^{* * *}$ & $0.8642^{* * *}$ & $1.6654^{* * *}$ & $3.1029^{* * *}$ & $0.8661^{* * *}$ & $1.5751^{* * *}$ \\
& $(0.2821)$ & $(0.3087)$ & $(0.2758)$ & $(0.2983)$ & $(0.3093)$ & $(0.2725)$ \\
& {$[11.45]$} & {$[2.8]$} & {$[6.04]$} & {$[10.40]$} & {$[2.8]$} & {$[5.78]$} \\
& & & & & &
\end{tabular}




\begin{tabular}{|c|c|c|c|c|c|c|}
\hline \multirow{2}{*}{$\begin{array}{l}\text { Independent } \\
\text { Variables }\end{array}$} & \multicolumn{3}{|c|}{ Model (1) } & \multicolumn{3}{|c|}{ Model (2) } \\
\hline & $\begin{array}{l}\text { Pooled } \\
\text { OLS }\end{array}$ & FE model & RE model & $\begin{array}{l}\text { Pooled } \\
\text { OLS }\end{array}$ & FE model & RE model \\
\hline \multirow[t]{3}{*}{ CAP_EXP } & 0.2404 & $0.3918^{*}$ & 0.3395 & 0.2936 & $0.3895^{*}$ & 0.3752 \\
\hline & $(0.3433)$ & $(0.2316)$ & $(0.2334)$ & $(0.3454)$ & $(0.2321)$ & $(0.2296)$ \\
\hline & {$[0.7]$} & [1.69] & [1.45] & {$[0.85]$} & {$[1.68]$} & {$[1.63]$} \\
\hline \multirow[t]{3}{*}{ LEVER } & $0.5609^{* * *}$ & 0.2480 & 0.3011 & $0.5628^{* * *}$ & 0.2694 & $0.3747^{*}$ \\
\hline & $(0.1643)$ & $(0.2735)$ & $(0.2048)$ & $(0.1642)$ & $(0.2770)$ & $(0.2028)$ \\
\hline & {$[3.41]$} & {$[0.91]$} & [1.47] & [3.43] & [0.97] & [1.85] \\
\hline \multirow[t]{3}{*}{ Constant } & $1.720^{* * *}$ & $-3.3545^{*}$ & 0.3499 & $1.6119^{* * *}$ & -3.1728 & 0.4388 \\
\hline & $(0.5340)$ & $(1.9077)$ & $(0.8190)$ & $(0.5410)$ & $(1.9426)$ & $(0.8073)$ \\
\hline & {$[3.22]$} & {$[-1.76]$} & {$[0.43]$} & [2.99] & {$[-1.63]$} & {$[0.54]$} \\
\hline Obs. & 309 & 309 & 309 & 309 & 309 & 309 \\
\hline N. & 103 & 103 & 103 & 103 & 103 & 103 \\
\hline F statistic & $25.91^{* * *}$ & $6.73^{* * *}$ & & $22.93^{* * *}$ & $5.90^{* * *}$ & \\
\hline Wald $\left(X^{2}\right)$ & & & $57.21^{* * *}$ & & & $70.10^{* * *}$ \\
\hline F Test & & $13.28^{* * *}$ & & & $13.15^{* * *}$ & \\
\hline $\mathrm{LM}\left(x^{2}\right)$ & & & $155.85^{\star * *}$ & & & $161.25^{\star * *}$ \\
\hline Hausman $\left(X^{2}\right)$ & & $75.16^{* * *}$ & & & $59.61^{* * *}$ & \\
\hline
\end{tabular}

Notes: F-test, LM-test, Hausman Test used to select suitable regression models; Standard errors are shown in parentheses (.); t-statistic are shown in brackets [.]; ${ }^{* * *} \mathrm{p}<0.01,{ }^{* *} \mathrm{p}<0.05$, and ${ }^{*} \mathrm{p}<0.1$

As mentioned before, the estimates from FE model may be biased and consistent due to the potential endogenous relation between CGI and Tobin's Q. We now re-estimate the regressions employing 2SLS. The results are shown in Table 5. The findings from TOBINQ equation in Table 5 show that our previous results are still robust (Column 1). In addition, there is a statistically significant relation between CGI score and firm value at $1 \%$. This result supports our doubt about the effectiveness of conventional variables as proxies for corporate governance practices. A set of overall indicators seems to reflect effectively "the quality" of corporate governance practices.

We next consider how the relation between corporate governance and firm value changes when existing pyramid structures. To do so, we firstly classify companies in the full sample into two groups: (i) non-existence; and (ii) existence of pyramid structure, then we estimate the relationship between CGI and firm value for each sub-sample separately. Column 2 and 3 show an interesting finding about the relation between corporate governance and firm value in Vietnam. For companies without pyramid structure, CGI is positively correlated with firm value at $5 \%$ (Column 2). On the opposite, there is no evidence supporting the positive relationship between firm value and CGI for firms with pyramid structure (Column 3).

In addition, it is argued that in firms owned by family, family members will have chances and abilities to achieve benefits but cost outside/minority shareholders (Fama \& Jensen, 1983). These 
chances and abilities will increase when these members maintain pyramid ownership (Connelly, Limpaphayom, \& Nagarajan, 2012). Therefore, we take this consideration into account by further classifying companies which have pyramid ownership into high and low family ownership. The regression results for these two groups are shown in Column 4 and 5 of Table 5. It seems that when existing pyramid structure, there is no significant relation between corporate governance and firm value even companies belong to high or low family ownership. 
Table 5

Regression results by 2SLS

\begin{tabular}{|c|c|c|c|c|c|c|c|c|c|c|}
\hline & \multicolumn{2}{|c|}{ Full sample } & \multicolumn{2}{|c|}{$\begin{array}{c}\text { Sub-sample } \\
\text { Non-existence } \\
\text { pyramid structure }\end{array}$} & \multicolumn{2}{|c|}{$\begin{array}{c}\text { Sub-sample } \\
\text { Existence } \\
\text { pyramid structure }\end{array}$} & \multicolumn{2}{|c|}{$\begin{array}{c}\text { Sub-sample } \\
\text { Existence } \\
\text { pyramid structure \& } \\
\text { high family ownership } \\
\text { (4) }\end{array}$} & \multicolumn{2}{|c|}{$\begin{array}{c}\text { Sub-sample } \\
\text { Existence } \\
\text { pyramid structure \& low } \\
\text { family ownership } \\
(5)\end{array}$} \\
\hline & TOBINQ & CGI & TOBINQ & CGI & TOBINQ & CGI & TOBINQ & CGI & TOBINQ & CGI \\
\hline CGI & $\begin{array}{c}0.0466^{* * *} \\
(0.0178) \\
{[2.62]}\end{array}$ & & $\begin{array}{c}0.0374^{* *} \\
(0.0166) \\
{[2.25]}\end{array}$ & & $\begin{array}{c}0.08305 \\
(0.0695) \\
{[1.19]}\end{array}$ & & $\begin{array}{c}-0.1142 \\
(0.2868) \\
{[-0.40]}\end{array}$ & & $\begin{array}{c}0.0294 \\
(0.0695) \\
{[0.42]}\end{array}$ & \\
\hline TOBINQ_A & $\begin{array}{c}-0.0645 \\
(0.0667) \\
{[-0.97]}\end{array}$ & $\begin{array}{c}1.4049 * * \\
(0.7087) \\
{[1.98]}\end{array}$ & $\begin{array}{c}-0.1100^{*} \\
(0.0580) \\
{[-1.9]}\end{array}$ & $\begin{array}{c}0.9133 \\
(0.7750) \\
{[1.18]}\end{array}$ & $\begin{array}{c}0.4958 \\
(0.2891) \\
{[1.72]}\end{array}$ & $\begin{array}{c}1.8198 \\
(1.8323) \\
{[0.99]}\end{array}$ & $\begin{array}{c}-0.3863 \\
(0.9154) \\
{[-0.42]}\end{array}$ & $\begin{array}{c}-2.3641 \\
(4.9721) \\
{[-0.48]}\end{array}$ & $\begin{array}{c}0.7189 * * \\
(0.596) \\
{[2.00]}\end{array}$ & $\begin{array}{c}3.4520 * \\
(1.8807) \\
{[1.84]}\end{array}$ \\
\hline BOD_SIZE & $\begin{array}{c}-0.0089 \\
(0.0231) \\
{[-0.39]}\end{array}$ & $\begin{array}{c}0.8166^{* * *} \\
(0.2056) \\
{[3.97]}\end{array}$ & $\begin{array}{c}0.0106 \\
(0.0189) \\
{[0.56]}\end{array}$ & $\begin{array}{c}0.5493^{* * *} \\
(0.2290) \\
{[2.40]}\end{array}$ & $\begin{array}{c}-0.1146 \\
(0.1036) \\
{[-1.11]}\end{array}$ & $\begin{array}{c}1.2211 \\
(0.4195) \\
{[2.91]}\end{array}$ & $\begin{array}{c}-0.2124 \\
(0.8156) \\
{[-0.26]}\end{array}$ & $\begin{array}{c}-2.5369 \\
(2.9798) \\
{[-0.85]}\end{array}$ & $\begin{array}{c}-0.0360 \\
(0.1123) \\
{[-0.32]}\end{array}$ & $\begin{array}{c}1.1311^{* *} \\
(0.5634) \\
{[2.01]}\end{array}$ \\
\hline BOD_IND & $\begin{array}{c}0.2124^{* *} \\
(0.1076) \\
{[1.97]}\end{array}$ & $\begin{array}{c}-2.7882^{* *} \\
(1.0943) \\
{[-2.55]}\end{array}$ & $\begin{array}{c}0.0896 \\
(0.0189) \\
{[0.56]}\end{array}$ & $\begin{array}{c}-1.6928 \\
(1.2931) \\
{[-1.31]}\end{array}$ & $\begin{array}{c}0.6593 \\
(0.4899) \\
{[1.35]}\end{array}$ & $\begin{array}{c}-5.9543^{* * *} \\
(1.8484) \\
{[-3.22]}\end{array}$ & $\begin{array}{c}-1.2825 \\
(2.0559) \\
{[-0.62]}\end{array}$ & $\begin{array}{c}-5.4560 \\
(10.7811) \\
{[-0.51]}\end{array}$ & $\begin{array}{c}0.2373 \\
(0.6989) \\
{[0.34]}\end{array}$ & $\begin{array}{c}-9.0824^{* * *} \\
(2.1039) \\
{[-4.32]}\end{array}$ \\
\hline SIZE & $\begin{array}{c}-0.0900^{* * *} \\
0.0249 \\
{[-3.61]}\end{array}$ & $\begin{array}{c}0.5492^{* *} \\
(0.2634) \\
{[2.08]}\end{array}$ & $\begin{array}{c}-0.0936^{* * *} \\
(0.0298) \\
{[-3.15]}\end{array}$ & $\begin{array}{c}1.1641^{* * *} \\
(0.3133) \\
{[3.72]}\end{array}$ & $\begin{array}{c}-0.0314 \\
(0.0790) \\
{[-0.40]}\end{array}$ & $\begin{array}{c}0.3843 \\
(0.5242) \\
{[0.73]}\end{array}$ & $\begin{array}{c}-0.5925 \\
(0.5295) \\
{[-1.12]}\end{array}$ & $\begin{array}{c}-1.3037 \\
(3.0310) \\
{[-0.43]}\end{array}$ & $\begin{array}{c}0.0157 \\
(0.1135) \\
{[0.14]}\end{array}$ & $\begin{array}{c}1.1290^{*} \\
(0.5759) \\
{[1.96]}\end{array}$ \\
\hline FIRM_AGE & $\begin{array}{c}0.0487 \\
(0.0451) \\
{[1.08]}\end{array}$ & $\begin{array}{c}0.6968 \\
(0.4972) \\
{[1.40]}\end{array}$ & $\begin{array}{c}0.0835^{* *} \\
(0.0415) \\
{[2.01]}\end{array}$ & $\begin{array}{c}-0.2288 \\
(0.5726) \\
{[-0.4]}\end{array}$ & $\begin{array}{c}0.0475 \\
(0.2269) \\
{[0.21]}\end{array}$ & $\begin{array}{c}2.6713^{* *} \\
(0.9189) \\
{[2.91]}\end{array}$ & $\begin{array}{c}-0.9913 \\
(2.5597) \\
{[-0.39]}\end{array}$ & $\begin{array}{c}-8.6482 \\
(5.1094) \\
{[-1.69]}\end{array}$ & $\begin{array}{c}0.2552 \\
(0.2916) \\
{[0.88]}\end{array}$ & $\begin{array}{c}3.6936^{* * *} \\
(0.9701) \\
{[3.81]}\end{array}$ \\
\hline $\mathrm{ROA}$ & $\begin{array}{c}2.4179^{* * *} \\
(0.4937)\end{array}$ & $\begin{array}{c}17.3114^{* * *} \\
(4.4186)\end{array}$ & $\begin{array}{c}2.5020^{* * *} \\
(0.4539)\end{array}$ & $\begin{array}{c}17.7842^{* * *} \\
(4.7723)\end{array}$ & $\begin{array}{c}1.9479 \\
(2.0441)\end{array}$ & $\begin{array}{l}20.0195^{*} \\
(10.5541)\end{array}$ & $\begin{array}{c}0.0870 \\
(8.3031)\end{array}$ & $\begin{array}{l}-20.0820 \\
(48.3555)\end{array}$ & $\begin{array}{c}3.0242 \\
(2.0473)\end{array}$ & $\begin{array}{l}19.6375^{*} \\
(10.7134)\end{array}$ \\
\hline
\end{tabular}




\begin{tabular}{|c|c|c|c|c|c|c|c|c|c|c|}
\hline & \multicolumn{2}{|c|}{ Full sample } & \multicolumn{2}{|c|}{$\begin{array}{c}\text { Sub-sample } \\
\text { Non-existence } \\
\text { pyramid structure } \\
\text { (2) }\end{array}$} & \multicolumn{2}{|c|}{$\begin{array}{l}\text { Sub-sample } \\
\text { Existence } \\
\text { pyramid structure } \\
\text { (3) }\end{array}$} & \multicolumn{2}{|c|}{$\begin{array}{c}\text { Sub-sample } \\
\text { Existence } \\
\text { pyramid structure \& } \\
\text { high family ownership } \\
\text { (4) }\end{array}$} & \multicolumn{2}{|c|}{$\begin{array}{c}\text { Sub-sample } \\
\text { Existence } \\
\text { pyramid structure \& low } \\
\text { family ownership } \\
\text { (5) }\end{array}$} \\
\hline & TOBINQ & CGI & TOBINQ & CGI & TOBINQ & CGI & TOBINQ & CGI & TOBINQ & CGI \\
\hline & [4.90] & [3.92] & [5.51] & [3.73] & [0.95] & [1.09] & {$[0.01]$} & {$[-0.42]$} & [1.48] & [1.83] \\
\hline CAP_EXP & $\begin{array}{c}0.6737 \\
(0.4228) \\
{[1.59]}\end{array}$ & $\begin{array}{c}-9.2917^{* *} \\
(4.4602) \\
{[-2.08]}\end{array}$ & $\begin{array}{c}0.3334 \\
(0.4643) \\
{[0.72]}\end{array}$ & $\begin{array}{c}-15.995^{* * *} \\
(5.2718) \\
(-3.03)\end{array}$ & $\begin{array}{c}1.2054 \\
(1.1118) \\
{[1.08]}\end{array}$ & $\begin{array}{c}1.0260 \\
(7.8196) \\
{[0.13]}\end{array}$ & $\begin{array}{c}0.8638 \\
(5.4201) \\
{[0.16]}\end{array}$ & $\begin{array}{c}10.5345 \\
(36.3843) \\
{[0.29]}\end{array}$ & $\begin{array}{c}1.0420 \\
(1.0336) \\
{[1.01]}\end{array}$ & $\begin{array}{c}0.1843 \\
(7.2587) \\
{[0.03]}\end{array}$ \\
\hline LEVER & $\begin{array}{c}0.5537 * * * \\
(0.1875) \\
{[2.95]}\end{array}$ & $\begin{array}{c}-0.1601 \\
(2.149) \\
{[0.07]}\end{array}$ & $\begin{array}{c}0.5909^{* * *} \\
(0.1786) \\
{[3.31]}\end{array}$ & $\begin{array}{c}1.6898 \\
(2.4416) \\
{[0.69]}\end{array}$ & $\begin{array}{c}0.9860 \\
(0.7648) \\
{[1.29]}\end{array}$ & $\begin{array}{c}-7.4130 * \\
(3.9838) \\
{[-1.86]}\end{array}$ & $\begin{array}{c}-1.6227 \\
(4.4824) \\
{[-0.36]}\end{array}$ & $\begin{array}{c}-15.0559 \\
(9.7146) \\
{[-1.55]}\end{array}$ & $\begin{array}{c}0.5546 \\
(0.8267) \\
{[0.67]}\end{array}$ & $\begin{array}{c}-7.7218^{*} \\
(4.4154) \\
{[-1.75]}\end{array}$ \\
\hline Constant & $\begin{array}{c}0.6726 \\
(0.7418) \\
{[0.91]}\end{array}$ & $\begin{array}{c}22.5068^{* * *} \\
(7.153) \\
{[3.15]}\end{array}$ & $\begin{array}{c}1.0348^{*} \\
(0.6240) \\
{[1.66]}\end{array}$ & $\begin{array}{c}10.4652 \\
(8.2964) \\
{[1.26]}\end{array}$ & $\begin{array}{c}-2.6101 \\
(2.5532) \\
{[-1.02]}\end{array}$ & $\begin{array}{c}18.7011 \\
(15.4885) \\
{[1.21]}\end{array}$ & $\begin{array}{c}28.5178 \\
(40.7416) \\
{[0.7]}\end{array}$ & $\begin{array}{c}136.6131 \\
(90.2229) \\
{[1.51]}\end{array}$ & $\begin{array}{c}-2.6353 \\
(2.3818) \\
{[-1.11]}\end{array}$ & $\begin{array}{c}-4.7268 \\
(16.5676) \\
{[-0.29]}\end{array}$ \\
\hline Obs. & 309 & 309 & 237 & 237 & 72 & 72 & 17 & 17 & 55 & 55 \\
\hline $\mathrm{R}^{2}$ & 0.2038 & 0.1899 & 0.2984 & 0.2228 & 0.3233 & 0.4377 & 0.4945 & 0.6730 & 0.5620 & 0.5733 \\
\hline
\end{tabular}

Notes: The sample in this study is devided into two groups including existence and non-existence pyramid structure. Furthurmore, the sub-samples which exist pyramid ownership are continuously classified into two groups including high and low family ownerships. Standard errors are shown in parentheses (.); t-statistic are shown in brackets [.]; ${ }^{* * *} \mathrm{p}<0.01,{ }^{* *} \mathrm{p}<0.05$, and ${ }^{*} \mathrm{p}<0.1$ 


\section{Conclusion}

This study analyzes the relation between corporate governance and firm value under the existence or non-existence of pyramid structure. The sample consists of 103 Vietnam's non-financial firms listed on HoSE during the period from 2012 to 2014. The finding of this study shows that CGI is a better proxy for corporate governance practices than conventional indicators, especially when existing pyramid ownership. The most interesting finding of this study is that good corporate governance practices will not have statistically significant in the relation to firm value if companies have pyramid structures. Even when we classify these companies into high and low family ownership, the results are unchanged. This implies that although CGI is a comprehensive proxy, using this index to evaluate corporate governance practices or make conclusions about the effect of corporate governance on firm value may be misleading if there is a presence of pyramid structures. Therefore, identifying the existence of pyramid structures is the fist essential step before cosidering the relation between corporate governance and firm value.

This research has some implications for policy makers and practitioners. In construction of corporate governance indicators, policy makers can concretize items, adjust items to make them suitable for Vietnamese context, as well as introduce more specific regulations on corporate governance practices.

For companies, board of directors and board of managements need to develop corporate governance regulations in detail and suit the industrial characteristics. In addition, if enterprises only focus on some prominent problems of corporate governance in the past, today CGI seems to be a benchmark for companies to identify fully interesting items.

For investors, effective corporate governance practices will contribute to increase firm value. Investors should be careful when evaluating the effectiveness of corporate governance. Our results imply that investors should be better to use CGI, instead of individual corporate governance indicators. Investors also need to identify whether pyramid structures exis 


\section{References}

Agrawal, A., \& Knoeber, C. R. (1996). Firm performance and mechanisms to control agency problems between managers and shareholders. Journal of Financial and Quantitative Analysis, 31, 377-397.

Andres, P. D., Azofra, V., \& Lopez, F. (2005). Corporate boards in OECD countries: Size, composition, functioning and effectiveness. Corporate Governance, 13(2), 197-210.

Barontini, R., \& Caprio, L. (2006). The effect of family control on firm value and performance: Evidence from continental Europe. European Financial Management, 12(5), 689-723.

Bebchuk, L., Cohen, A., \& Ferrell, A. (2009). What matters in corporate governance? Review of Financial Studies, 22(2), 783-827.

Bertrand, M., Mehta, P., \& Mullainathan, S. (2002). Ferreting out tunneling: An application to Indian business groups. The Quarterly Journal of Economics, 117(1), 121-148.

Black, B., Jang, H., \& Kim, W. (2006). Does corporate governance predict firms' market values? Evidence from Korea. Journal of Law, Economics, and Organization, 22, 366-413.

Brown, L., \& Caylor, M. (2006). Corporate governance and firm operating performance. Journal of Accounting and Public Policy, 25(4), 409-434.

Chen, C. W., Lin, J. B., \& Yi, B. (2008). CEO duality and firm performance: An endogenous issue. Corporate Ownership and Control, 6(1), 58-65.

Cheung, Y. L., Connelly, J. T., Limpaphayom, P., \& Zhou, L. (2007). Do investors really value corporate governance? Evidence from the Hong Kong market. Journal of International Financial Management and Accounting, 18, 86-122.

Cheung, Y.-L., Connelly, J. T., Estanislao, J. P., Limpaphayom, P., Lu, T., \& Utama, S. (2014). The corporate governance and firm valuation in Asian emerging markets. In S. Boubaker \& D. K. Nguyen (Eds.), Corporate governance in emerging markets: Theories, practices and cases (pp. 27-53). Springer, New York.

Claessens, S., Djankov, S., \& Lang, L. (2000). The separation of ownership and control in East Asian corporations. Journal of Financial Economics, 58(1-2), 81-112.

Claessens, S., Djankov, S., Fan, J. P., \& Lang, L. (2002). Disentangling the incentive and entrenchment effects of large shareholding. Journal of Finance, 57(6), 2741-2771.

Connelly, J. T., Limpaphayom, P., \& Nagarajan, N. J. (2012). Form versus substance: The effect of ownership structure and corporate governance on firm value in Thailand. Journal of Banking E Finance, 36, 1722-1743. doi:10.1016/j.jbankfin.2012.01.017

Daraghma, Z., \& Alsinawi, A. (2010). Board of directors, management ownership, and capital structure and its effect on performance: The case of palestine securities exchange. International Journal of Business and Management, 5(11), 118-127.

Drobetz, W., Schillhofer, A., \& Zimmerman, H. (2003). Corporate governance and expected 
stock returns: Evide nce from Germany. European Financial Management, 10(2), 267-293.

Eisenberg, T., Sundgren, S., \& Wells, M. T. (1998). Larger board size and decreasing firm value in small firms. Journal of Financial Economics, 48(1). 35-54.

Eisenhardt, K. M. (1989). Agency theory: An assessment and review. Academy of Management Review, 14(1), 57-74.

Fama, E. F., \& Jensen, M. E. (1983). Separation of ownership and control. The Journal of Law and Economics, 26, 301-325.

Gompers, P., Ishii, J., \& Metrick, A. (2003). Corporate governance and equity prices. Quarterly Journal of Economics, 118(1), 107-155.

Hermalin, B. E., \& Weisbach, M. S. (1991). The effects of board composition and direct incentives on firm performance. Financial Management, 20(04), 101-112.

Hermalin, B. E., \& Weisbach, M. S. (2003). Boards of directors as an endogenously determined institution: A survey of the economic literature. Economic Policy Review, 9, 7-26.

Himmelberg, C. P., Hubbard, R. G., \& Palia, D. (1999). Understanding the determinants of managerial ownership and the link between ownership and performance. Journal of Financial Economics, 53, 353-384.

Jensen, M. C., \& Meckling, W. H. (1976). Theory of the firm: Managerial behavior, agency costs and ownership structure. Journal of Financial Economics, 3(4), 305-360.

La Porta, R., Lopez-de-Silanes, F., \& Shleifer, A. (1999). Corporate ownership around the world. Journal of Finance, 54(2), 471-517.

Lehn, K., Patro, S., \& Zhao, M. (2007). Governance indexes and valuation: Which causes which? Journal of Corporate Finance, 13(5), 907-928.

Lemmon, M., \& Lins, K. (2003). Ownership structure, corporate governance, and firm value: Evidence from the East Asian financial crisis. The Journal of Finance, 58(4), 1445-1468.

Lins, K. V. (2003). Equity ownership and firm value in emerging markets. Journal of Financial and Quantitative Analysis, 38, 159-184.

Morck, R., Shleifer, A., \& Vishny, R. W. (1988). Management ownership and market valuation: An empirical analysis. Journal of Financial Economics, 20, 293-315.

OECD. (1999). Principles of corporate governance. Paris.

OECD. (2004). Principles of corporate governance. Paris.

Rouf, A. (2011). The relationship between corporate governance and value of the firm in developing countries: Evidence from Bangladesh. The International Journal of Applied Economics and Finance, 5(3), 237-244.

Turki, A., \& Sedrine, N. (2012). Ownership structure, board characteristics and corporate performance in Tunisia. International Journal of Business and Management, 7(4), 121-132.

Villalonga, B., \& Amit, R. (2006). How do family ownership control and management affect 
firm value? Journal of Financial Economics, 80, 385-417.

Xia, L. (2008). Founder control, ownership structure and firm value: Evidence from entrepreneurial listed firms in China. China Journal of Accounting Research, 1, 31-49.

Yermack, D. (1996). Higher market values of companies with a small board of directors. Journal of Financial Economics, 40(2), 185-211. 